\title{
PROTECIVE ROLE OF VITAMIN E ON LEAD INDUCED NEUROTOXICITY IN MALE ALBINO RATS
}

\author{
Ali Sadek Sawan and Ayman A. Nagy* \\ Pathology Department, Faculty of Medicine, King Abdul Aziz University, KSA. \\ *Forensic Medicine and Clinical Toxicology Department, Tanta university, Egypt
}

\begin{abstract}
Lead is a pervasive environmental toxin that affects multiple organ systems, including the nervous, renal, reproductive and hematological systems. Even though lead is probably the most studied toxic metal, some of the symptoms of lead toxicity still cannot be explained by the known molecular mechanisms. Therefore, lead induced oxidative stress has recently started to gain attention. This experimental study is planned to investigate the- role of oxidative stress as a possible mechanism of sub-chronic lead induced neurotoxicity in rats and to evaluate the role of alphatocopherol (Vitamin E) as anti oxidant in reversing this effect.

In order to achieve our goal, we measured both the blood level. Morever, the enzyme activities of reduced glutathione (GSH), glutathioneperoxidase $(\mathrm{GPx})$, superoxide dismutase (SOD), malondialdhyde (MDA), 8-hydrodydeoxyguanosine (8-OHdG) were determinedin brain tissues of lead acetate exposed rats in the presence or absence of Vit. E. Increases in MDA, 8- OHdG contents were observed in brain's of rats received only lead acetate but supplementation with Vit. E returned these measures to nearly pretreatment levels. The level of GSH, SOD and GPx. significantly decreased in lead acetate exposed rats but increased to about pretreatment levels in supplementation of Vit.E concomitantly to lead acetate treated rats. This study also showed that administration of lead acetate to male rats had elevated blood and brain lead level which not decreased on administration of Vit. E concomitantly. To confirm these results a histopathological examination of rats brain were done. Histopathological changes were observed in the brain of lead exposed rats in the form of sever edema, gliosis, and neuronal degeneration, but addition of Vit. E concomitantly to lead showed mild changes in the form of mild edema, and gliosis. These results suggests that Vit.E can protect against oxidative stress effect of lead inducing neurotoxicity by its antioxidant effect, but not associated with decreasing brain or blood lead level.
\end{abstract}

\section{INTRODUCTION}

Lead is an ancient metal. It is widely used by Man since prehistoric time, because of its malleability, resistance to corrosion and low mellting point. Lead is one of the most toxic and pervasive pollutant in society and is known to have toxic effects on several biological systems. Although population on exposure to lead his been declined in recent years as a result of change to lead free gasoline, lead is still the most serious environmental hazard to young children ${ }^{(1,2)}$.

In Humans Lead can result in a wide range of biological effects depending upon the level and duration of exposure. The major exposure pathway in the general non smoking population is from food, water and air ${ }^{(3,4,5)}$.Epidemiologic studies over the past several decades have suggested that even slightly elevated lead levels during early childhood can produce cognitive impairments and behavioral problems that endure long past the period of exposure ${ }^{(6)}$.

Lead poisoning is largely a disorder of young children with a peak incidence in one to three years of age. The relatively fast growth and metabolic rates of children coupled with their small body size are in themselves predisposing factors to susceptibility to lead toxicity. Adults with occupational exposure to lead constitute another large group at risk ${ }^{(7,8)}$.

Elevated concentrations of blood lead levels in children who are chronically exposed to low levels of lead may be a cause of CNS toxicity including learning disabilities, lowered intelligence Quotient (IQ) and behavioral abnormalities; in addition to lead encephalopathy $(9,10,11,12,13)$.

Although no single mechanism for lead toxicity has yet been defined, recent studies indicate that at least some lead induced damage may occur as a consequence of lead -induced oxidative stress ${ }^{(14,15,16)}$. Lead- induced oxidative stress has led scientists to study the protective qualities of antioxidants against lead toxicity ${ }^{(17,18,16)}$.

The aim of this study is to investigate the role of oxidative stress as a possible mechanism of subchronic lead toxicity induced neurotoxicity in rats and to evaluate the role of alphatocopherol Vitamin E as antioxidant in reversing that effect.

\section{MATERIAL AND METHODS}

This is an experimental study that was conducted on 50 adult male albino rats weighting 100 $150 \mathrm{gm}$. Purchased from Helwan resenrch animal Center. The animals were fed on ordinary food and housed in ordinary conditions in the animal house in 
Ali S. Sawan and Ayman A, Nagy

the department of forensic medicino and toxicology, faculty of medicine Tanta University. Rats were divided randomly into five groups, 10 rals each (n $-10)$ :-

Group (Group I) Served as a negative control group and received nothing.

Group (Group 2) Served as a positive control group and received intraperitoncal injection of sodium acetate in dose of $1 \mathrm{mg} / \mathrm{kg} /$ day for four weeks.

Group (Group 3) Served as a positive control group and received olive oil orally in dose of 54 $\mathrm{mg} / \mathrm{kg} /$ day for four weeks.

Group (Group 4) Received intra peritoneal injection of lead acetate in dose of $1 \mathrm{mg} / \mathrm{kg}$ b.w. /day for four weeks ${ }^{(19)}$,

Group (Group 5) Received the same dose for the same period of lead acetate in dose of $1 \mathrm{mg} / \mathrm{kg}$ b.w. /day for four weeks in addition to Vit. E orally in a dose of $54 \mathrm{mg} / \mathrm{Kg} /$ day dissolved in olive oil ${ }^{(20)}$.

A pilot study had been done to compare the results of all positive control groups. The study included sodium acetate as a positive control of lead acetate, de-ionized water and olive oil as a solvent for lead acetate and Vit . E. respectively. The duration of this experiment was 4 weeks, Lead acetate and sodium acetate were obtained from Aldrich, chemical company, Germany. Vitamin E was purchased from Sigma chemical Company. St. Louis, USA, At the end of the experimental period, the rats were sacrificed by cervical dislocation, blood samples were collected by heart puncture into clear sterile tubes, and then the whole brain were excised and washed from extraneous materials. How it kept?

Metal analyșis: whole blood and brain tissue lead levels were determined by atomic absorption spectrophotometer Model 2380 Perkin-Elmer ${ }^{(21)}$.

Determination of reduced glatathione: Reduced glutathione was determined in brain tissue using double beam spectrophotometer, according to method described by Richardson and Murphy, 1975(22), Results were obtained from standard curve and expressed in nmol /gm tissue.

Determination of Glutnilitone peroxldase activity! Glutathione peroxidase activity was determined in animal's brain thase using double beam spectrophotometer, according to method described by Urisini et al.,1995 ${ }^{\text {(3)! }}$

Determination of Supernatant protein contents: Protein contents of supernatant was measured colorimetrically using double beam spectrophotometer, according to method described by Lowery et al.,1951 (24).

Determination of Super oxide dismutase activity:Sper oxide dismutase was determined in animal's brain tissue using double beam spectrophotometer, as described by Arther and Boyne,1985 ${ }^{(25)}$. Using Ransod kit (Randox laboratories limited),

Determination of Lipid per oxidation: Lipid per oxidation was determined in animal's brain tissue using double beam spectrophotometer, Using thiobarbituric acid method according to method described by Uchiyama and Mihara, $1978^{(26)}$. Result were obtained from standard curve and expressed in nmol /gm tissue.

Determination of 8-Hydroxy deoxyguanosine (8OHdG): 8-hydroxy deoxyguanosine (8-OHdG) contents in the animal's brain were determined after enzymatic digestion of DNA, followed by HPLC detection, as described by Shigenaga et al., $1990^{(27)}$,

Iristopathological examination of brain sections of all groups: Immediately after sacrificing the animals, sections from the brain were removed and immediately fixed in buffered formalin 10\%, 0.5 thickness slices were cut and processed, paraffin embedded, then paraffin embedded sections were cut and stained with H\&E stain to be studied with light microscope. All sections were evaluated without prior knowledge of the animal treatment groups by the examiner.

Statistical Analysis

Statistical presentation and analysis of the present study was conducted, using the mean, Standard Deviation [SD], t. test analysis of variance [ANOVA] test. p. value significant less than $0.05(p<0.05)$ 


\section{RESULTS}

The pilot study showed non significant changes between all control groups and sodium acetate treated group as well as olive oil treated group were used as a represented group.

Oxidative status:-

The rate brain tissues levels of reduced glutathione (GSH) in animals [treated with $1 \mathrm{mg} / \mathrm{kg}$ b.w. /day for four wecks group (4)] were significantly lower than those observed in control groups $\mathrm{P}<0.05$. Treatment with Vitamin $E$ in a dose of $54 \mathrm{mg} / \mathrm{Kg} /$ day coneomitantly with lead [group (5)] enhanced significantly increase in GSH in animals brain tissues in comparison to group (4) $p<0.05$, as shown in Table (1). The activities of glutathione peroxidase GPx and superoxide dismutase SOD in rat brain tissues of lead treated group (group 4) were significantly decreased ( $n$ comparison to the control groups $p<0.05$. However, a significant increase in GPx and SOD activity were detected in lead \& Vit . E treated group (group5) in comparison to group (4) $\mathrm{p}<0.05$. as shown in table ( 2 , 3) respectively. As regard to the contents of malonaldhyde (MDA) as an end product of lipid perxidation nerve cells membrane as measured by double beam spectrophotometer) and 8- Hydroxy deoxyguanosine (8- OHdG) of rat brain contents as measured by HPLC are shown in table $(4,5)$ respectively. The activities of MDA and 8-OHdG contents of rat brain tissues in the lead only treated group (group 4) were significantly increased (in comparison to the control groups. $\mathrm{p}<0.05$. However, a significant decrease in MDA and 8- OHdG contents of the brain tissues were measured in lead \& Vit , E treated group (group5) in comparison to group (4) $p<0.05$. On the other hand the mean values of blood and brain lead level among different studied groups. were significantly higher in intraperitoneal injection of lead acetate with or without oral administration of vitamin E (group 4\&5) compared to lead unexposed groups (control groups). There is no reduction in blood and brain lead level on administration of Vitamin $\mathrm{E}$. There was no significant difference between + ve \& ve control groups as shown in Table (6).

The histopathological findings

The histopathological study confirmed the previous results. Photomicrograph (1) showed the brain contained normal amount of glial cells without pathological changes in controle group. On there hand, in studying sections from group (4) that received intraperitoneal injection of lead acetate ( $1 \mathrm{mg} / \mathrm{kg} / \mathrm{day}$ ) for 4 weeks, Brain sections from all studied rats showed Extensive gliosis, oedema and Subpial mononuclear cellular infiltration (Photomicrograph 2). While Photomicrograph 3 showed mild oedema and gliosis in sections from group (5) that received lead acetate $(1 \mathrm{mg} / \mathrm{kg} /$ day) intraperitoneally concomitantly with vit E orally in dose $(54 \mathrm{mg} / \mathrm{kg} / \mathrm{dy})$ for 4 weeks.

\section{DISCUSSION}

Lead is an abundant toxic metal that primarily affects the peripheral and central systems, red blood cells and calcium metabolism (28). Exposure to environmental lead is particularly neurotoxic to the developing nervous system of children's. Neurotoxic effects of lead exposure include memory impairment, lowering of IQ and increased reaction time. ${ }^{(29,30,31,32,33)}$.

One of the major concepts on the mechanism of heavy metals toxicity is attributed to its ability to generate reactive oxygen species (ROS) which causes peroxidation of membrane lipids and DNA degeneration. ROS formation in the tissue was likely to cause oxidative damage and oxidative stress which could be contributed to tissue injury in liver, brain, kidney and other organs ${ }^{(3+, 5)}$. Usually the deleterious effects of the oxidative stress are counteracted by natural cellular defense mechanisms that involve enzymatic and non enzymatic scavengers of free radicals ${ }^{(36)}$.

Recent studies reported that lipids peroxidation in neuronal cells was accentuated following lead exposure, also the antioxidant capacity of the neuronal 
cells was diminished. So they suggested that lead may exert its neurotoxic effects via per oxidative damige to the membrane an?

Based on the above considerations this study was carried out to investigate the role of oxidative stress in lead induced neurotoxicity and to study the possible protective effect of vit. E against lead induced oxidative stress in rat's brain.

The present study revealed significant reduction of the measured antioxidant scavenger such as reduced glutathione (GSH) and glutathione peroxidase (GPx) and super oxide dismutase (SOD) enzymes, following exposure to lead acetate. These finding are consistent with the finding of others who reported that lead decrease GSH level in brain, which has been proposed as a sensitive indicator of oxidative stress (0ennes). Other workers have also reported a decrease in GPx activity in brain of lead exposed rats which might attribute to exhaustion or inactivation of the GPx enzyme by lead induced ROS ${ }^{(23,40)}$. Similar results were reported as a decrease in SOD activity in brain of rats received lead acetate ${ }^{(41,40,42)}$.

In this study; vit. $\mathrm{E}$ was found to have a protective effect against lead induced reduction in GSH, GPx, SOD such effect was observed in rats received vit.E concurrently with lead acetate which show significant elevation in the previous parameters in brain of treated animals as compared to lead acetated treated rats. Possible mechanisms were postulated for these activities, which could be explained by the antioxidant capability of vit . $\mathrm{E}^{(37)}$.

Malonadialdehyde (MDA) is an end product of the lipid peroxidation process, which can be defined as oxidative deterioration of poly unsaturated lipid. ${ }^{(3)}$, It was reported that oxidative stress may cause several types of DNA lesions, 8-hydroxy deoxyguanosine (8OHdG) is one of the most formed oxidative DNA lesions, that can be detected in both urine and tissues after oxidative stress ${ }^{(44)}$.

In the current study, a significant elevation was observed in brain MDA level as well as $8-0$ HdG in brain DNA of the lead acetate exposed rats. This is in agrecinent with A charys and Achung $1997^{\text {in }}$ \& Patra

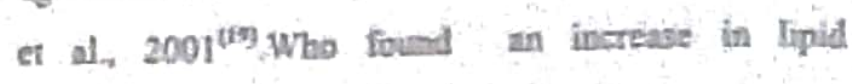
peroxidation in krain tisubes of rats exposed to lead aceate, these resuls in agreenent with the previvis findings of mary authors who formd an increase in level of $8 \mathrm{HAG}$ in liver, kidncy, lang and aperme fats

Results of the present investigation showed that VR . E decreased the MDA levels as well as B-OHul level significantly in rat's brain, when cdministrated concomitantly with lead as contrared to rits of group(4). The previous results may be attributed to the effect of vit. E, which is a major lipid solable, chain breaking antioxidant that is known to protect kiologieal membranes and lipoproteins from peroxidative damuse (ate), It scavenges $\mathrm{O}_{2} \mathrm{OH}$, lipid peroxyl radicals, and other ROS generated during the woivalent redbetion of molecular oxygen and during normal activity of oxidative enzymes $^{(6)}$. Vit.E was found to inhibit DetA oxidative damage in many studier. So the ebserved reduction of the elevated \&-OHdG levels in vil E trealled rats, could be aftributed to the anti- oxidant effect of wit $\mathrm{E}^{(50) .50)}$.

In the present study, blood lead level showed nos significant change in lead acetate treated mas, compared with lead and vit. $\mathrm{E}$ treated rats. This denotes that the protective effect of vit. $\mathrm{E}$ as an antioxidan? inhibiting lead related oxidative stress was not associated with reduction of blood lead level. These results were supported by Hsu et al, 1998 $8^{(50)}$, Who studied the effects of Vit .E and /or Vit .C on reactive oxygen oxygen species related lead toxicity in rat's sperms. They stated that the protective effect of Vir. E or C was not accompanied by decreasing lead blood level in animals.

A confirmatory study of the effects of lead and Vit, E las been performed, through a bistopathological examination of the brain. In this study, histopathological changes were observed in brain of lead exposed rats, including edema, gliosis and neuronal degeneration. Such alterations in the brain tissues could be induced through a direct action of lead on astroglaial cells and membranes lipid peroxidation 
of brain capillaries. These observation were in agreement with previous studies, that indicated capillary damage, neuronal degeneration, astroglajal and proliferation in the brain of lead exposed rats as, lead was first localized in capillary endothelial cells and then in astrocyles $(51,52,50,34)$.

In the current study brain tissues of rats received Vit E concomitantly with lead showed lower damage in the form of mild edema, and mild gliosis. This could be explained by the antioxidant effect of Vit, E. ${ }^{(0,19,40)}$.
According to the obtained results, Vit.E by its antioxidant abilify might be suggested to protect agrinst oxidative stress effect of lead inducing netrotoxicity. However, this protective effect is not associated with decreasing brain or blood lead level. Therefore, it is advisable to give Vit.E as anti oxidant to protect against lead inducing neurotoxicity, especially to children, and enforce all protective measures againat lend environmental pollution.

Table (1): Effect of lead acetate (I P) with or without oral administration of vitamin E on Redaced glutathione (GSF) contents in rat's brain.

\begin{tabular}{|c|c|c|c|c|c|}
\hline & \multicolumn{5}{|c|}{ Treatment } \\
\hline & -ve control & Sodium acetate & Olive oil & Lead acetate & $\begin{array}{c}\text { Lead } \\
\text { acelate + } \\
\text { Vit. E }\end{array}$ \\
\hline $\begin{array}{c}\text { Brain GSH Level } \\
\text { (nmol /g tissuc) } \\
\text { Mean } \pm S D\end{array}$ & $653 \pm 16$ & $650 \pm 12$ & $654 \pm 14$ & $530 \pm 11.6^{3}$ & $648 \pm 10^{b}$ \\
\hline
\end{tabular}

(a) mean significant difference as compared to control groups $p<0.05$.

(b) mean significant difference as compared to lead acetate treated group. $\mathrm{p}<0.05$.

Table (2): Effect of lead acetate (I P) with or without vitamin E on glutathione Peroxidas (GPx) activity in rat's brain.

\begin{tabular}{|c|c|c|c|c|c|}
\hline & \multicolumn{3}{|c|}{ Treatment } \\
\cline { 2 - 5 } & -ve control & Sodium acetate & Olive oil & Llead acetate & lead acetate + Vic E \\
\hline $\begin{array}{c}\text { Brain Gpx Level } \\
(\mu \text { mol INDPH/min } \\
\text { /g protein) } \\
\text { Mean } \pm \text { SD }\end{array}$ & $157.73 \pm 6.21$ & $156 \pm 7.10$ & $157 \pm 6.67$ & $132 \pm 8.2^{\mathrm{a}}$ & $156 \pm 798^{\mathrm{b}}$ \\
\hline
\end{tabular}

(a) mean significant difference as compared to control groups $\mathrm{p}<0.05$.

(b) mean significant difference as compared to lead acctate treated group. $\mathrm{p}<0.05$.

Table (3): Effect of lead acetate with or without vitamin E on Superoxide dismutase (SOD) activity in rat's brain.

\begin{tabular}{|c|c|c|c|c|c|}
\hline & \multicolumn{3}{|c|}{ Treatment } \\
\cline { 2 - 5 } & -ve control & Sodium acetate & Olive oil & Lead acetate & Lead acetate + Vit. \\
\hline $\begin{array}{c}\text { Brain SOD } \\
(\mu / g \text { Protein }) \\
\text { Mean } \pm S D\end{array}$ & $50.30 \pm 0.24$ & $50.00 \pm 0.31$ & $50 \pm 0.35$ & $40.20 \pm 0.40^{\circ}$ & $48.00 \pm 0.60^{\mathrm{b}}$ \\
\hline
\end{tabular}


Ali S, Sawan and Ayman A. Nagy

(a) mean significant difference as compared to control groups $\mathrm{p}<0.05$.

(b) mean significant difference as compared to lead acetate treated group. $\mathrm{p}<0.05$.

Table (4): Effect of lead acetate with or without vitamin E on Malonaldehyde (MDA) content in rat's brain.

\begin{tabular}{|c|c|c|c|c|c|}
\hline & \multicolumn{5}{|c|}{ Treatment } \\
\cline { 2 - 6 } & -ve control & Sodium acetate & Olive oil & Lead acetate & Lead acetate + vif. E \\
\hline $\begin{array}{c}\text { Brain MDA } \\
\text { (nmolig lisiuc) Mean } \\
\pm \text { SD }\end{array}$ & $117.60 \pm 3.10$ & $116.50 \pm 3.50$ & $117.34 \pm 4.2$ & $222.00 \pm 1.80^{\mathrm{a}}$ & $140.00 \pm 2.70^{\mathrm{b}}$ \\
\hline
\end{tabular}

(a) mean significant difference as compared to control groups $p<0.05$.

(b) mean significant difference as compared to lead acetate treated group. $\mathrm{p}<0.05$.

Table (5): Efrect of lead acetate with or without vitamin E on 8-Hydroxydeoxyguanosine (8-OHdG) content in rai's brain.

\begin{tabular}{|c|c|c|c|c|c|}
\hline & \multicolumn{4}{|c|}{ Treatment } \\
\cline { 2 - 5 } & -ve control & $\begin{array}{c}\text { Sodium acetate } \\
\text { treated })\end{array}$ & Olive oil & Lead acetate & $\begin{array}{c}\text { Lead acclate }+ \\
\text { Vit. E treated }\end{array}$ \\
\hline $\begin{array}{c}\text { Brain 8- OHdG } \\
\text { (fmol/mg protein) } \\
\text { Mean } \pm \text { SD }\end{array}$ & $14.1220 \pm 1.30$ & $14.2000 \pm 1.60$ & $14.001 \pm 1.89$ & $29.7500 \pm 2.50^{\circ}$ & $17.3600 \pm 1.71^{\mathrm{b}}$ \\
\hline
\end{tabular}

(a) mean significant difference as compared to control groups $p<005$.

(b) mean significant difference as compared to lead acetate treated group. $\mathrm{p}<0.05$.

Table (6): Show changes in lead blood and brain tissues contents administration of lead acetate (I P) with or without vitamin $E$ in rats.

\begin{tabular}{|c|c|c|c|c|c|}
\hline & \multicolumn{5}{|c|}{ Treatment } \\
\cline { 2 - 6 } & ve control & Sedium aceate & Olive oil & Lead acetate & $\begin{array}{c}\text { Lead acetate + } \\
\text { Vit. E }\end{array}$ \\
\hline Blood lead lowel (ppm) & $7.52 \pm 0.32$ & $7.72 \pm 0.24$ & $7.58 \pm 0.45$ & $66.23 \pm 0.56^{\mathrm{a}}$ & $65.43 \pm 0.76^{\mathrm{b}}$ \\
\hline Brain lead level (ppm) & $0.75 \pm 006$ & $0.76 \pm 0.03$ & $0.75 \pm 0.07$ & $7.6 \pm 1.34^{\mathrm{a}}$ & $7.1 \pm 1.1^{\mathrm{b}}$ \\
\hline
\end{tabular}

(a) mean significant difference as compared to control groups $p<0.05$.

(b) mean siguificant difference as compared to lead acetate treatud group. p $<0.05$.

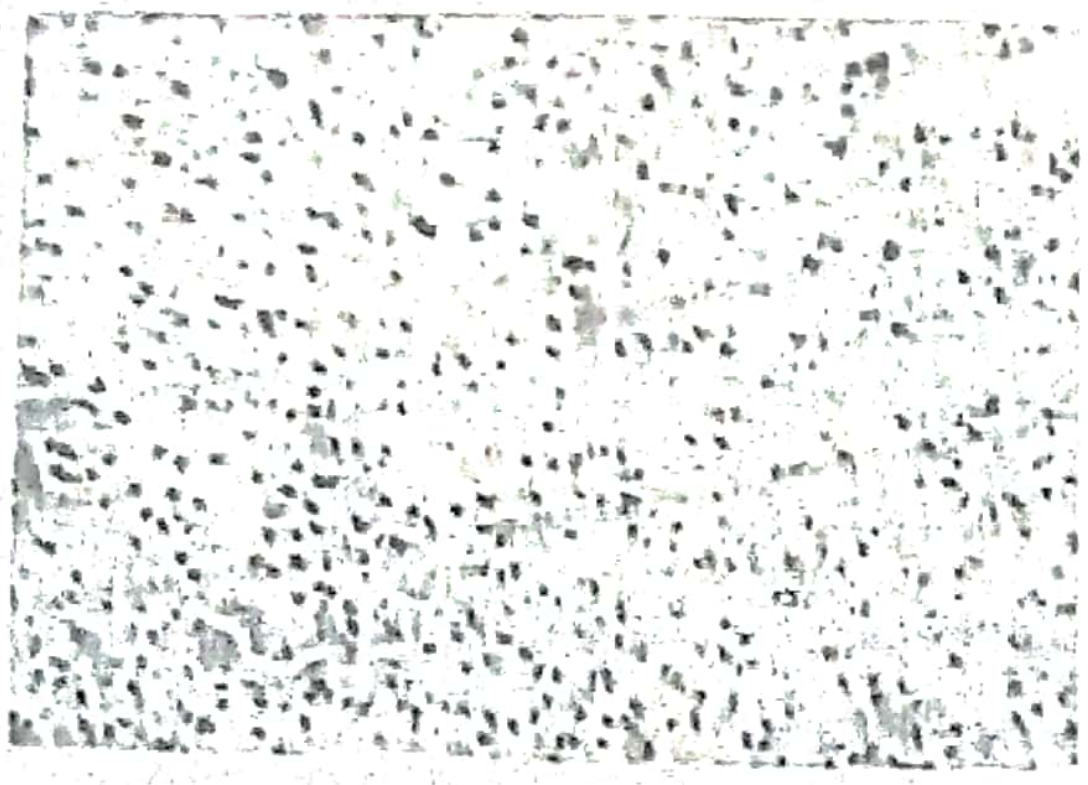


Photomicrograph (1) Brain section from control rats; showing normal cells and normal amount of glial cells. $(\mathrm{H} \& \mathrm{E} \times 125)$

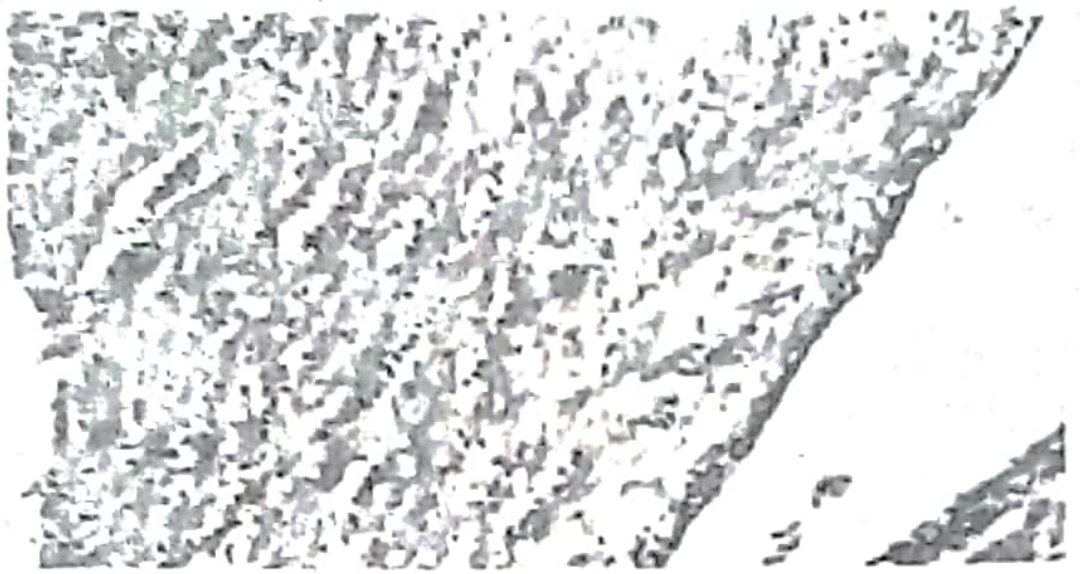

Photomicrograph (2) Brain section from Rats received lead acetate for four weeks showing extensive gliosis $(G)$ and oedema (E) with subpial mononuclear cellular infiltration (M).

(H \& E *125)

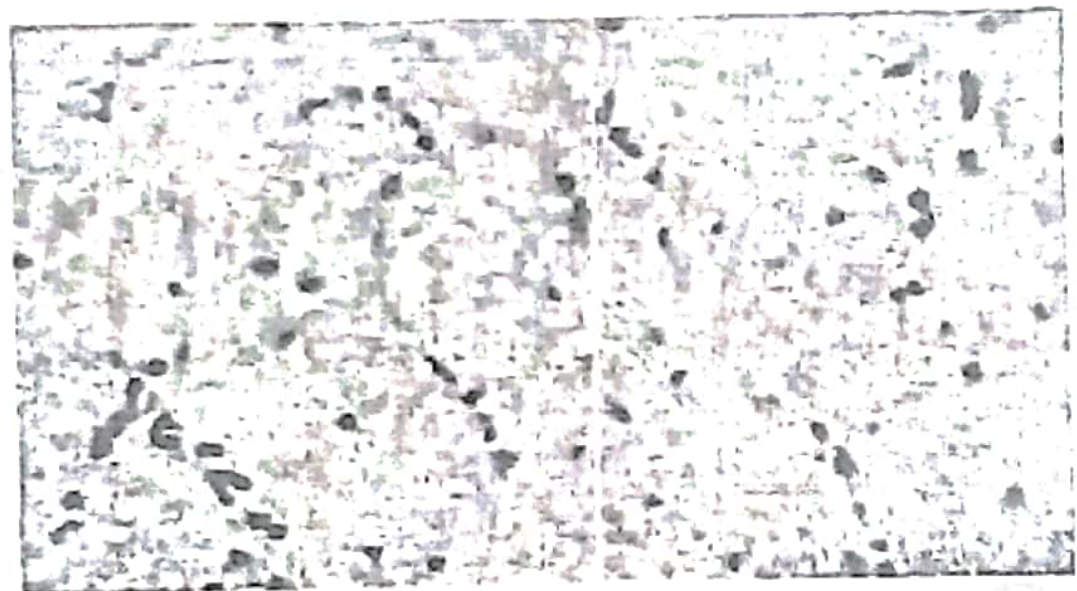

Photomicrograph (3) Brain section from Rats received lead acetate $1 \mathrm{mg} / \mathrm{kg} / \mathrm{day}$ (IP) concomitantly with Vit. E orally in dose of $(54 \mathrm{mg} / \mathrm{kg} /$ day) for four weeks; showing mild gliosis (G) and oedema (E).

$(\mathrm{H} \& \mathrm{E} \times 125)$

\section{REFERENCES}

1. Landrigan PJ, Boffetta P, Apostoli P:, Am J Ind Med.;38: 231-243, (2000).

2. Reglero MM., Taggart MA., Castellanos P., Mateo R: Environ Pollut.;157: 2209-2215, (2009).

3. Mahaffey KR, Annest JL, Roberts J: 1976-1980, (1982).

4. Zigiany $M$, Huagian $M$, Xiulan: Mutat. Res.;334: 244-246 (1995).

5. Beyer WN., Gaston G., Brazzle R., O'Connell A.F., Audet D.J: Deer exposed to exceptionally high concentrations of lead near the continental mine in Idaho, USA. Environmental Toxicology and Chemistry;26:1040-1046 (2007).

6. Diane ES, Myla SS, Donald S, Mareike K and Barbara JS: Reductions in blood lead overestimate reductions in brain lead following repeated succimer regimens in a rodent model of childhood lead exposure, Environ Health Prespect.; 112: 302308 (2004).

7. Mushak P, Crocetti AF: Determination of number of Lead exposed American children as a function of lead source, Environ Res,; 50: 211-229, (1989.)

8. Colborn T: Endocrine disruption from environmental toxicants. In Environmental and Occupational Medicine. 3rd ed, LippincottRaven.:p.808. (1998)

9. Baker El Jr, Landrigan $\mathrm{Pj}$, Barbour $\mathrm{Ag}, \mathrm{Cox} \cdot \mathrm{DH}$, Folland DS, Ligo RN, Throckmorton J; Occupational lead poisoning in the united state: Clinical and biochemical findings related to blood lead levels. Br J Ind Med.; 36(4):314-322 (1979) 
Ali S. Sawan and Ayman A. Nagy

10. Bandbury MW: The structure and function of the blood brain barrier. Fed Pros.; 43! 186-190. (1984)

11. Needleman HL, Schell A, Beeinger D, Leviton A, Allred EN: The long term effects of exposure to lead in childhood. $N$ Engl J Med.; 322; 83-88, (1990).

12. Altman $L_{3}$ Weinsberg $F$, Sveinsson $K$, Lilenthal $H$, Weiganed $\mathrm{H}$, and Winnekc $\mathrm{G}$ : Impairment of long term potentiation and learing following chronio lead exposure. Toxicol letier.;66:105-112 , (199:)

13. Klaaseen CD: Heavy metals and heavy metal antagonists. In Goodman and Gilman's: The pharmacological basis of therapeutics. $9^{\text {th }} \mathrm{ed}$. McGraw-Hill, New York,.(2001)

14. Soltaninejad K, Kebriaceezadeh A, Minaiee B, Ostad SN, Hossseini R, Azizi E and abdollahi M: Biochemical and ultrastructural evidences for roxizity of lead through free radicals in rat brain. Hum. Exp.Toxicol.;22:417-423. (2003)

15. Reglero MM., Monsalve-González L., Taggart MA., Mateo R: Transfer of metals to plants and red deer in an old lead mining area in Spain, Science of the Total Environment;406: 287-297. (2008)

16. Reglero MM., Taggart MA., Monsalve-González L., Mate R o: Heavy metal exposure in large gane from a lead mining area: effects on oxidative stress and fatty acid composition in liver. Environmental Pollution a;157: 1388-1395. (2009)

17. Nukhet $A B$ and Nuran $E:$ Effects of selenocystine on lead exposed Chinese hamster ovary (CHO) and PC-12 cells, Toxicol and Applied Pharmacol,; 214:136-143. (2006)

18. Chaurasia SS, Panda S, Kar A: Withania somnifera root extract in regulation of lead induced oxidative damage in male mouse. Pharnicol Res; 4l(6): 663-666. (2000)

19. Patra RC, Swarup D, Dwivedi SK: Antioxidant effects of a- tocopherol, ascorbic acid and Lmethionine on lead induced oxidative stress to the liver, kidney and brain in rats. Toxicology.;16?: 81-88. (2001)
20. Kessopoulu E, Powers HJ, Sharma KR, Pearson MI: A double blind randomized placebo croes over controlled trial using the antioxidant Vitamin $E$ to Lreat reactive oxygen essocisted male infertility, Fertility and sterility.; 64(4): 825-831. (1995)

21. AOAC Association of official analytical chemisss; 13 $13^{\text {th }}$ c.d. Washington, D.C. (1980)

22. Richardson RJ, Murphy SD: Effect of glututhione depletion on tissue deposition of melhyl metcury in rats. Toxicol Appl Pharmcol; 31: 505-519. (1975)

23. Ursini $F$, Maiorino $M$, Brigelius- Flabe $R$, Aumann KD, Roveri A, Schomburg D, Flohe L: Diversiny of glutathione perozidases. Methods Enzyymol.; 252:38-53. (1995)

24. Lowery OH, Rosebrough NJ, Farr AL, Randall EJ: Protein measurements with the folin phemol reagent. J. Biol.Chem.; 183: 265-278. (1951)

25. Arthur JR, Boyne R: superoxide dismutase and glutathione peroxidase activities in neutrophils from selenium deficient and copper deficient cattle. life SCi,; 36(160): 1569-1575. 1985

26. Uchiyama M, Mihara M: Determimation of malondialdhyde precursor in tissues by thiobarbituric acid test. Anal Biochem; 86: 271 278. (1978)

27. Shigenaga MK, Park JW, Cundy KC, Gimeno C and Ames BN: In vivo oxidative DNA damager Measurement of 8- hydroxyl-2- deoxyguanosine in DNA and urine by high-performance liquid chromatography with electrochemical detection. Methods Enzymol,; 105:521-530. (1990)

28. Nehru B and Kanwar. SS: N- acetylecysteine exposure on lead - induced lipid peroxidative damage and oxidative defense system in brain regions of rats. Biol. Trace Elem. Res.; 101:257. 264. (2004)

29. De Silva PE: Determination of lead in plasma and studies in its relationship to lead in erythrocytes. Br J Ind Md.; 38: 209-217, (1981) 
30. Bressler J, Kim KA, Chakraborti T, Goldstein G: Mechanism of lead neurotoxicity. Neurochem Res.; 24: 595-600. (1999)

31. Ghorbe F, Boujelbene M, Makni-Ayadi F, Guremazi F, Kammoun A, Murat J, Croute F, Soleihavoup JP, El -Feki A: Effects of chronic lead exposure on kidney function in malc and female rats, determination of alead exposure biomarker. Arch Pysiol Biochem.; 109(5): 457. 463. (2001)

32. Sant'Ana MG, Spinosa HS, Florio JC, Bernardi MM, Oliveiria CA, Sarkis JE, Kakazu MH: Role of early $\mathrm{GnRH}$ administration in sexual behavior disorders of rat pups perinatally exposed to lead. Neurotoxicol Teratol.; 23 (2): 203-212. (2001)

33. Tchernitchin NN, Clavero A, Mena MA, Unde C, Villagra $R$, Cumsile $M$, Tchernitchin AN: Effect of chronic exposure to lead on estrogen action in the prepubertal rat uterus. Environ Toxicol.; 18(4): 268-277. (2003)

34. Halliwell B: Free radicals antioxidants and human disease: curiosity, cause or consequence? Lancet.; 344:721-724 - (1994)

35. Garber MM, Heiman AS: The in vitro effects of $\mathrm{Pb}$ acetate on NO production by $\mathrm{C} 6$ glial cells. Toxicol in Vitro.; 16: 499-508.( 2002)

36. Chen L, Lowery SR: Cellular antioxidant defense system. Prog Biol Res.; 287:247-256. (1989)

37. Adonaylo $\mathrm{VN}$, and Oteiza PI: $\mathrm{Pb}^{2+}$ promotes lipid oxidation and alteration in membrane physical properities. Toxicology.; 132(1):19-32. (1999)

38. Gurer H, Oztezcan S, Ercal N: Antioxidant role a lipoic acid in lead toxicity. Free Radic Biol Med.; 26: 75-81. (1999)

39. Gurer H, Ercal, N: Can antioxidants be beneficial in the treatment of lead poisoning. Free Radic Biol Med.; 29:927-945. (2000)

40. Flora SJ, Pande M, Mehta A: Beneficial effect of combained administration of some naturally occurring antioxidants (vitamins), and thiol chelators in the treatment of chronic lead intoxication. Chem Biol Interact.; 145: 267-280. (2003)

41. Minami M, Koshi K, Homma K, Suzuki Y: Changes of the activities of superoxide dismutase after exposure to the fumes of heavy metals and the significance of zinc in the tissue. Arch Toxicoli; 49(3-4): 215-225. (1982)

42. El Sokkary GH, Kamel ES, Reiter RU: Prophylactic effect of melatonin in reducing lead induced neuroloxicity in rats. Cell Mol Biol Lett; 8(2): 461-470. (2003)

43. De zwart II, Mecrman JH, Commandeur JNM, and Vermeulen NP: Biomarkers of free radical damage application in experimental animals and in humans. Free Radic Biol Med.; 26: 202-226. (1999)

44. Greenberg MM: In vitro and in vivo effects of oxidative damage to deoxyguanosine. Biochem Soc Trans.; 32: 46-50. (2004)

45. Acharya S, Acharya UR: In vivo Lipid peroxidation responses of tissues in lead treated Swiss mice. Ind Health.; 35(4): 542-544 . (1997)

46. Schilderman PA, Hoogewerff JA, Van Schooten FJ, Maas LM, Moon EJ, Van Os BJ, Van Wijnen $\mathrm{JH}$, Kleinjans Jc: Posible relevance of pigeons as an indicator species for monitoring air pollution. Environ Health Prespect.; 105(3): 322-330. (1997)

47. Xu Dx, Shen Hm, Zhu QX, Chua L, Wang QN, Chia SE, Ong $\mathrm{CN}$ : The association among semen quality, oxidative DNA damage in human spermatozoa and concentrations of cadmium, lead and selenium in seminal plasina. Mut Res.; 534: $155-163$. (2003)

48. Packer L: Protective role of vitamin E in biological systems. Am J Clin Nutr.; 53:1051-1055. (1991)

49. Jones DP, Kagan VE, Aust SD, Reed DJ, Omaye ST: Impact of neutrients on cellular lipid peroxidation and antioxidant defense system. Fundam Appl Toxicol.; 26: 1-7. (1995)

50. Hsu PC, Liu MY, Chen LY, Gue, YL: Effect of Vitamin $\mathrm{E}$ and /or $\mathrm{C}$ on reactive oxygen species- 
Ali S. Sawan and Ayman A. Nagy

related to lead toxicity in net spern Toxicology;128:169-179. (1998)

51. Thoms JA, Dallenbach FD, Thornes Mi The distribution of radioactive lead $(210 \mathrm{~Pb})$ in the cerebellum of developing rats. J Pathol.; 109:4550. (1973)

52. Tifrany - Castiglioni E, Garcia,DM, Wu N, Zmudzki J, Bratton GR: Effects of lead on Viability and intracellular metal content of C6 rat glioma cells. J Toxicol Environ Health.; $23: 267-$ 279. (1988)
53. Chang LW: Toxisoneurology and neuropathology induced by metale. In Texicology of metals, (chang LW ED: )i S11-S35CRC lewis Publlahers, New york. (1996)

54. Struzyuska $h$ Walski $M$, Gadarmald in, Dabrowska- Bouta B, Rafilowska U: Lead indoced abnormalities in blood brain barrier peconeability in experimental chronic toxicity. Mol Chen Neuropathology : 31(3):207-2240, (1997)

Received: January, 03, 2010 Accepted: March 01, 2010 


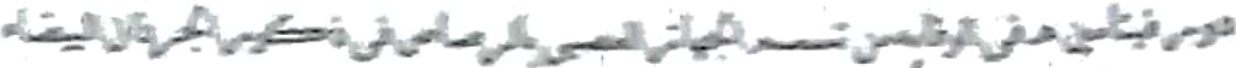

\section{"}

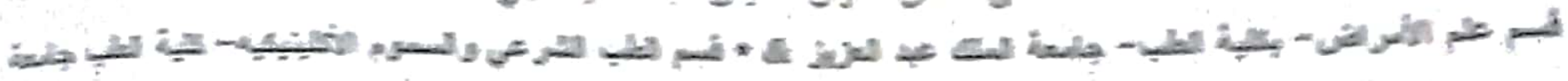
내는

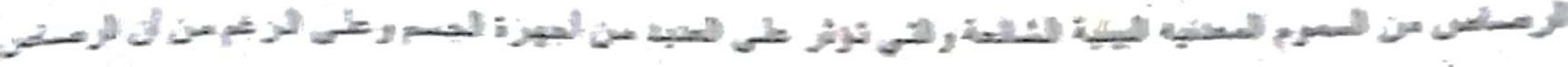

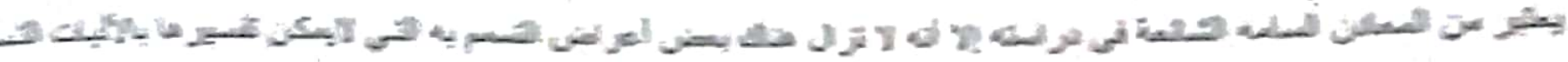

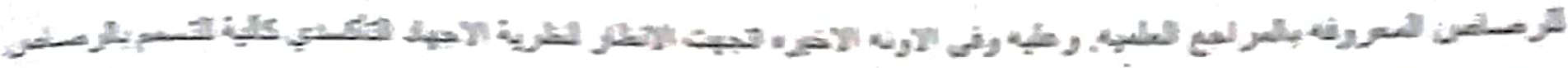

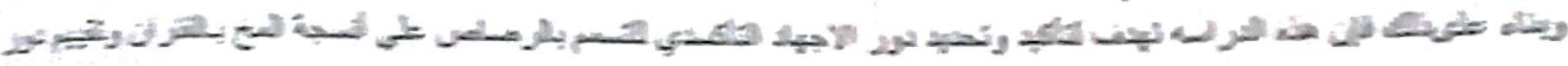

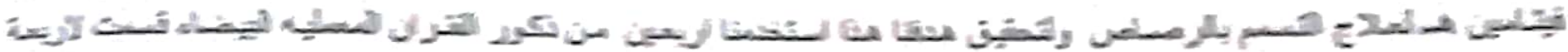
س

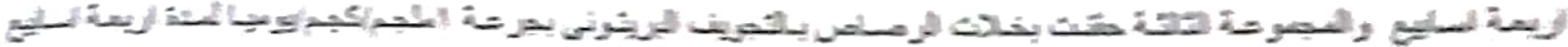

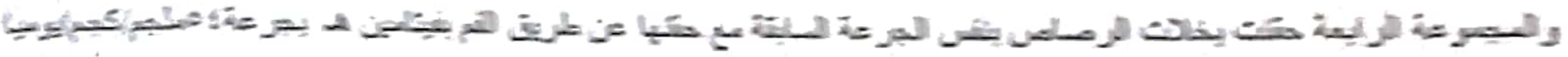

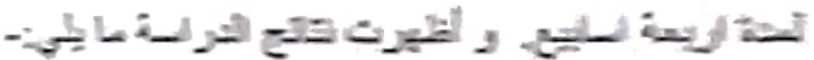

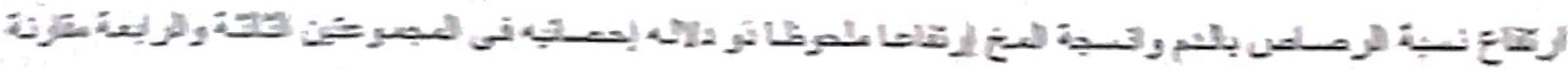
要

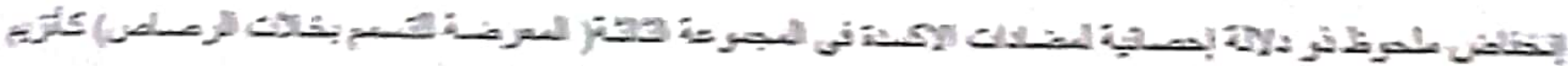

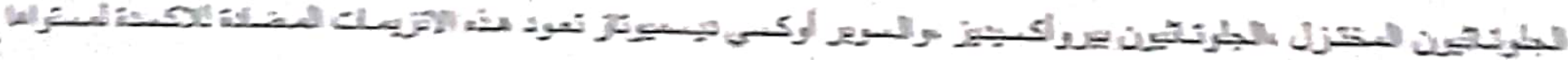

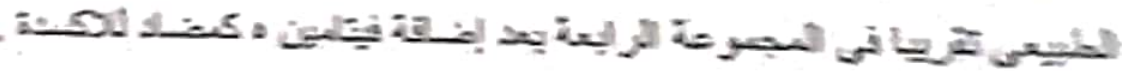

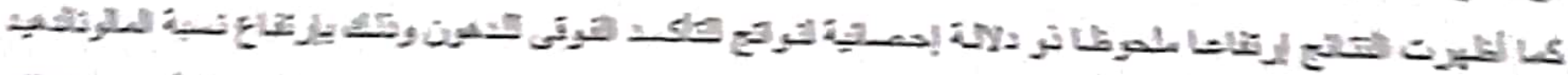

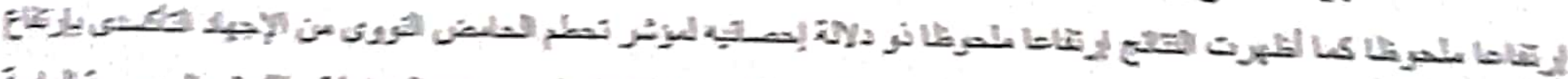

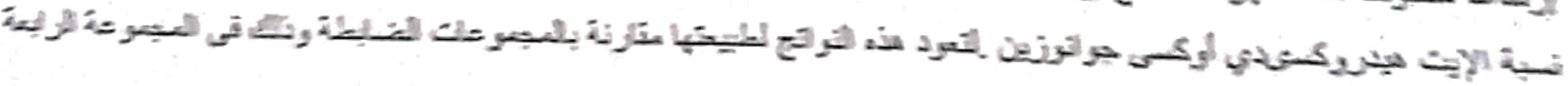

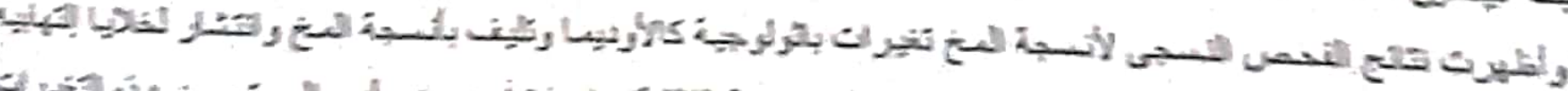

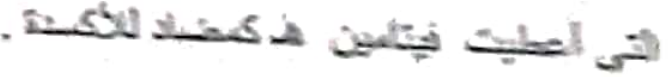

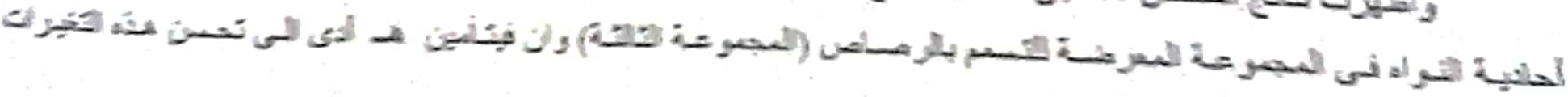

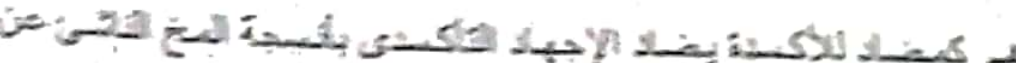

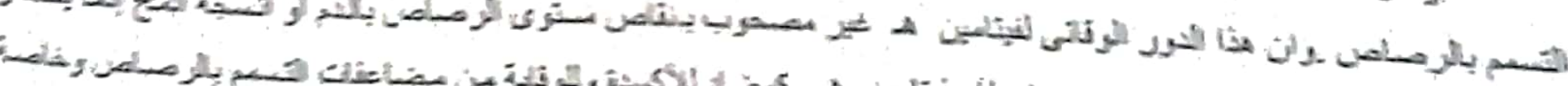

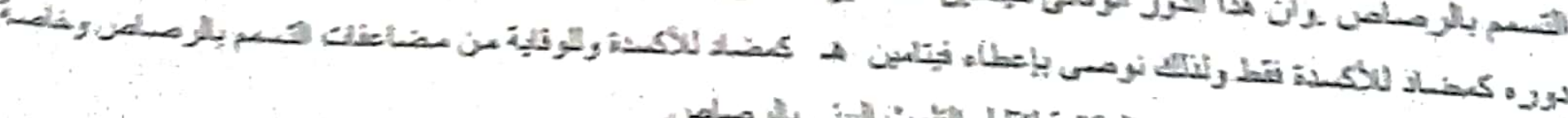

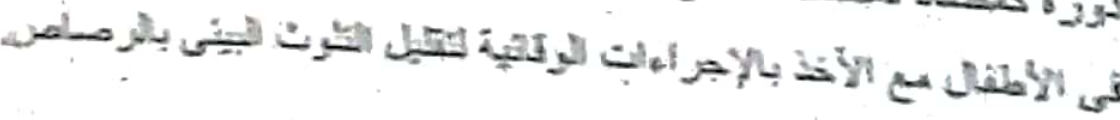

